\title{
PENGARUH PERHATIAN ORANG TUA DAN HASIL BELAJAR SISWA DI PERUMAHAN GRAHA MAS SERPONG UTARA
}

\author{
Zubairi Muzakki \\ STAI Asy-Syukriyyah \\ zubairimuzakki@gmail.com \\ Dahari \\ STAI Asy-Syukriyyah \\ dahari@asy-syukriyyah.ac.id
}

\begin{abstract}
Pendidikan merupakan kebutuhan dasar setiap manusiaPendidikan bukan sesuatu yang ada dengan sendirinya akan tetapi harus diusahakan oleh manusia. hal ini menjadi landasan bagi mayoritas orang tua dan penyelenggaran pendidikan baik itu dari pihak pemerintah maupun dari pihak swasta untuk membangun generasi penerus. Riset ini bertujuan untuk melihat seberapa besar pengaruh orang tua atau dalam hal ini adalah perhatian orang tua terhadap hasil belajar siswa yang dimana ini terjadi di era covid saat ini. Adapun metode penelitian nya adalah penelitian kuantitatif. Hasil dari penelitian ini menunjukkan bahwa ada pengaruh positif antara perhatian orang tua terhadap hasil belajr siswa yakni berdasarkan uji F, F hitung sebesar 11,702 lebih besar dari F tabel sebesar 7,31 artinya Fhitung $>F_{\text {Tabel }}$ Maka ada pengaruh perhatian orang tua terhadp hasil belajr siswa.
\end{abstract}

Keywords: Pengaruh, Perhatian, Orang Tua, Hasil belajar

\section{PENDAHULUAN}

Pendidikan merupakan kebutuhan dasar setiap manusia. Dengan pendidikan, manusia akan mampu membangun masa depan dan peradabannya. Masa depan yang cerah dan peradaban yang maju tidak akan dapat dicapai tanpa adanya pendidikan. Pendidikan merupakan kegiatan esensial dalam kehidupan manusia, karena dengan pendidikan manusia dapat dibedakan dengan makhluk lain yang ada di alam ini. Kenyataan seperti ini menunjukkan bahwa manusia memerlukan pendidikan.

Pendidikan bukan sesuatu yang ada dengan sendirinya akan tetapi harus diusahakan oleh manusia. hal ini menjadi landasan bagi mayoritas orang tua dan penyelenggaran pendidikan baik itu dari pihak pemerintah maupun dari pihak swasta untuk membangun generasi penerus. ${ }^{1}$ Pada dasarnya pendidikan yang berkualitas bukan hanya membutuhkan sekolah saja akan tetapi juga mebutuhkan stake holder sekolah yang termasuk didalamnya

\footnotetext{
${ }^{1}$ Mohamad, N., Dahari, D., \& Utama, M. M. A. (2021). Konsep Dan Strategi Menciptakan Pendidikan Karakter Di Madrasah. Jurnal Asy-Syukriyyah, 22(1): 60.
} 
adalah orang tua. Tidak serta merta dengan melepas tanggungjawab pendidikan sepenuhnya kepada sekolah.

Orang tua mempunyai peran penting dalam keberhasilan belajar siswa karena di sekolah para siswa hanya mungkin sekitar 8-9 Jam saja sisanya di rumah bersama keluarga. Hal yang menarik Indonesia bahkan dunia sedang menghadapi pandemi Covid 19 dimana semua kegiatan berbagai sektor kebanyakan WFH (Work From Home) bahkan juga berimbas di sektor pendidikan yang jadinya adalah BDR (Belajar dari Rumah).

Aktifitas pendidikan di masa pandemi Covid-19 saat ini sangatlah terganggu, sehingga banyak proses pendidikan formal anak tidak terpenuhi secara maksimal dan optimal dikarenakan adanya kebijakan belajar daring atau online yang belum diimbangi dengan kesiapan sarana prasarana serta kesiapan mental orang tua. Seperti riset yang dilakukan oleh rofiqul Penelitian ini merupakan pengembangan penelitian yang ada dimana kajian tetang perhatian orang tua masih minim apalagi terkait dengan era covid saat ini. ${ }^{2}$

Ternyata di masa pandemi Covid-19 ini tidak semua tugas mendidik dapat dilakukan oleh orang tua dalam keluarga di Perumahan Graha Mas Serpong Utara, sementara orang tua harus mengambil alih proses pendidikan dan pengajarannya selama kebijakan belajar secara daring atau online, hal inilah yang menjadi problem orang tua. Dimana orang tua harus bekerja dan mengurus urusan rumah dan keluarga, namun pada saat yang sama harus mengurus kegiatan belajar anak secara online. Dari pemaparan tersebut penulis tertarik mengangkat bagaimana kaitan serta hubungan antara Perhatian Orang tua dan Hasil belajar siswa di Perumahan Graha Mas Serpong Utara.

\section{KAJIAN TEORI \\ Perhatian Orang Tua}

Perhatian merupakan pemusatan psikis, salah satu aspek psikologis yang tertuju pada suatu objek yang datang dari dalam dan luar diri individu. Dengan perhatian dapat digunakan untuk meramalkan tingkah laku atau perbuatan manusia dalam kehidupan sehari-hari. Orang tua berperan sebagai pembentuk karakter dan pola fikir dan kepribadian anak. Oleh karena itu, keluarga merupakan tempat dimana anak-anaknya pertama kali berkenalan dengan nilai dan norma.

\footnotetext{
${ }^{2}$ Rofiqul A'la dan Muhamad Rifa'i Subhi, "Perhatian Orang Tua dan Motivasi Belajar Siswa," Madaniyah 6, no. 2 (2016): 242-59.
} 
Perhatian timbul karena ada dua hal yang merupakan bisa menjadi sebabnya munculnya dari perhatian:

1. Spontan

2. Perhatian yang tidak spontan. ${ }^{3}$

Kedua perhatian ini yang menjadi benang pembedanya adalah dari letak kemauan serta motivasi dari masing masing individu, jika perhatian spontan ini atas kemauan dari individu maka perhatian tidak spontan tidak atas $i d$ dia

Di dalam keluarga Meskipun tidak terdapat rumusan kurikulum dan program resmi dalam melaksanakan kegiatan pembelajaran, akan tetapi sifat pembelajaran di dalam keluarga sangat potensial dan mendasar.

Perhatian orang tua merupakan salah satu faktor yang dapat mendukung prestasi belajar siswa, Hal ini terkait dengan dukungan dan arahan serta bimbingan siswa dalam kegiatan belajar selama di rumah. ${ }^{4}$ Dimyati menyatakan bahwa "diantara faktor-faktor yang berasal dari keluarga, yang paling mungkin berpengaruh terhadap prestasi belajar anak di sekolah adalah tingkat perhatian orang tua. ${ }^{5}$

Maka peran keluarga terutama orangtua khususnya seorang ibu sebagai penentu dari berhasil tidaknya anak. Sebab orangtua adalah orang terdekat dengan anaknya yang senantiasa menemani dan merawat sejak kecil hingga dewasa kelak. Sedangkan keberadaan ayah hanyalah bekerja mencari nafkah yang otomatis waktunya banyak dihabiskan di luar rumah. Dari itulah ibu harus pandai-pandai mengatur dan membagi waktu untuk anak, mana yang digunakan belajar atau sekolah, bermain, berkumpul keluarga, bersenda gurau dan sebagainya. Sehingga kehidupan mereka berharga laksana perhiasan kehidupan dunia. Untuk mendidik anak yang benar haruslah dengan cara-cara yang baik, dan ini biasanya hanya bisa dilakukan oleh ibu. Maka ia dituntut harus memahami betul-betul sifat dan watak anak-anaknya yang kebanyakan terdapat perbedaan. Sehingga dia dengan mudah dapat masuk kedalam jiwa itu dan menyelam kedalam dunia mereka dengan nilai-nilai yang tinggi sesuai dengan ajaran agama, sifat-sifat terpuji dan akhlakul karimah.

\footnotetext{
${ }^{3}$ Walgito, Bimo. 2002. Pengantar Psikologi Umum. Yogyakarta: Andi Offset.h 79-80

${ }^{4}$ Rita Ningsih. (2016). Pengaruh kemandirian Belajar,dan Perhatian Orang Tua Terhadap Prestasi Belajar Matematika. Jurnal Formatif, 6(1): 76.

${ }^{5}$ Dimyati. 2006. Belajar dan Pembeljaran. Jakrta: Rineka Cipta:. h.9
} 
Berdasarkan pemaparan diatas maka penulis menyimpulkan perhatian orang tua adalah pemusatan psikis Orang tua terhadap anak baik terjadi spontan maupun tidak spontan yang berguna mewujudkan anak menjadi jiwa yang lebih baik.

\section{Hasil Belajar Siswa}

Matlin berpendapat bahwa belajar adalah suatu perubahan tingkah laku yang relatif permanen sebagai hasil dari pengalaman. Selanjutnya dalam konteks sekolah, belajar adalah suatu proses usaha yang dilakukan siswa untuk memperoleh suatu perubahan tingkah laku secara keseluruhan, sebagai hasil pengalaman siswa sendiri dalam interaksi dengan lingkungannya. ${ }^{6}$

Secara umum dapat didefenisikan bahwa hasil belajarmerupakanpenilaian diri siswa ${ }^{7}$ dan perubahanyang dapatdiamati, dibuktikan, dan terukur dalam kemampuan atau prestasi yang dialami oleh siswa sebagai hasil dari pengalaman belajar ${ }^{8}$ Proits mengungkapkan bahwa hasil belajar dapat menggambarkan kemampuan siswa setelah apa yang mereka ketahui dan pelajari ${ }^{9}$. Selanjutnya Robert Gagne berpendapat bahwa hasil belajar siswa terbagi menjadi lima kategori yaitu informasi verbal, keterampilan intelektual, keterampilan motorik, sikap dan strategi kognitif

Hasil belajar siswa dipengaruhi oleh dua faktor yaitu faktor internal dan faktor eksternal siswa. Faktor internal siswa diantaranya meliputi gangguan kesehatan, cacat tubuh, faktor psikologis (intelegensi, minat belajar, perhatian, bakat, motivasi, kematangan dan kesiapan peserta didik), dan faktor kelelahan. Sedangkan faktor eksternal yang mempengaruhi proses dan hasil belajar siswa meliputi faktor keluarga, sekolah dan masyarakat. ${ }^{10}$

\section{METODE PENELITIAN}

Penelitian ini merupakan penelitian kuantitatif. Metode yang digunakan dalam penelitian ini adalah metode kuantitatif. Teknik ini digunakan untuk membandingkan hasil

\footnotetext{
${ }^{6}$ Akbar, R., \& Hawadi. 2004. Akselerasi: A-Z Program Percepatan Belajar dan Anak Berbakat Intelektual.Jakarta: Grasindo. H.17

${ }^{7}$ Young, M. E., Klemz, B. R., \& Murphy, J. W. (2003). Enhancing Learning Outcomes: The Effects of Instructional Technology, Learning Style, Instructional Methods and Student Behavior. Journal of Marketing Education, 25, 130

${ }^{8}$ Nemeth, J., \& Long, J. G. (2012). Assessing Learning Outcomes in U.S. Planning Studio Courses. Journal of Planning Education and Research, 32(4), 476-490.

${ }^{9}$ Djiwandono, S. E. 2002. Psikologi Pendidikan.Jakarta: Grasindo. h.7

${ }^{10}$ Majid, A. (2008). Perencanaan Pembelajaran.Bandung: Remaja Rosdakarya. h.21
} 
pengukuran antara dua variabel yang berbeda agar dapat menentukan memperoleh informasi mengenai taraf hubungan yang terjadi antara dua variabel tersebut. Teknik korelasi dalam metode penelitian ini yang digunakan adalah korelasional.

Adapun variabel riset ini ada dua yakni bebas dan terikat yang kami gambarkan dalam bentuk gambar sebagai berikut

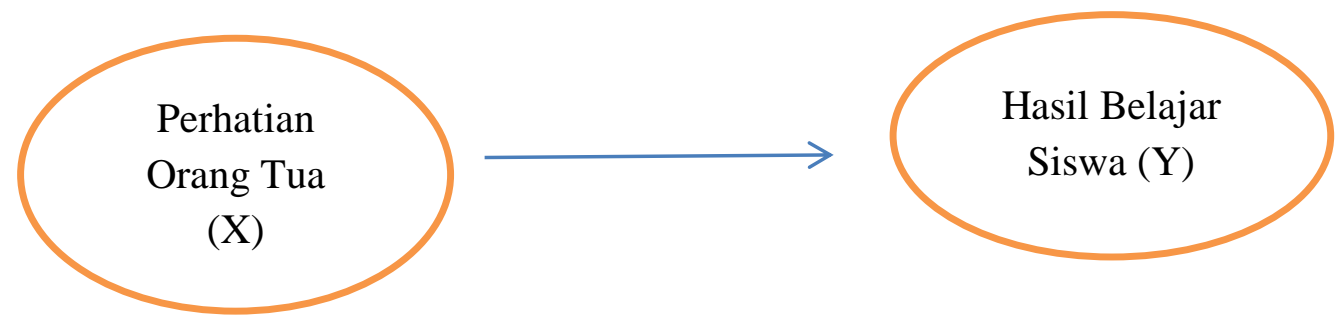

Adapun Responden dalam penelitian ini berjumlah 40 orang tua siwa yang ada di di Perumahan Graha Mas Serpong Utara. Pengumpulan data dalam penelitian ini menggunakan quesioner atau angket yang menjadi instruimen utama dalam riset ini .

\section{PEMBAHASAN}

Analisis Pengaruh Perhatian Orang Tua Terhadap Hasil Belajar Siswa

Tabel. 1

Uji Hipotesis Data Hasil Penelitian

\begin{tabular}{|r|r|r|r|r|r|}
\hline Responden & \multicolumn{1}{|c|}{$\mathbf{X}$} & \multicolumn{1}{|c|}{$\mathbf{Y}$} & \multicolumn{1}{|c|}{$\mathbf{X}^{\mathbf{2}}$} & \multicolumn{1}{|c|}{$\mathbf{Y}^{\mathbf{2}}$} & \multicolumn{1}{|c|}{$\mathbf{X}$} \\
\hline 1 & 77 & 83 & 5929 & 6889 & 6391 \\
\hline 2 & 59 & 84 & 3481 & 7056 & 4956 \\
\hline 3 & 93 & 89 & 8649 & 7921 & 8277 \\
\hline 4 & 94 & 85 & 8836 & 7225 & 7990 \\
\hline 5 & 95 & 86 & 9025 & 7396 & 8170 \\
\hline 6 & 101 & 89 & 10201 & 7921 & 8989 \\
\hline 7 & 94 & 89 & 8836 & 7921 & 8366 \\
\hline 8 & 98 & 93 & 9604 & 8649 & 9114 \\
\hline 9 & 75 & 82 & 5625 & 6724 & 6150 \\
\hline 10 & 91 & 82 & 8281 & 6724 & 7462 \\
\hline 11 & 93 & 91 & 8649 & 8281 & 8463 \\
\hline 12 & 101 & 81 & 10201 & 6561 & 8181 \\
\hline 13 & 107 & 65 & 11449 & 4225 & 6955 \\
\hline 14 & 104 & 75 & 10816 & 5625 & 7800 \\
\hline 15 & 101 & 84 & 10201 & 7056 & 8484 \\
\hline 16 & 90 & 88 & 8100 & 7744 & 7920 \\
\hline 17 & 115 & 89 & 13225 & 7921 & 10235 \\
\hline 18 & 113 & 93 & 12769 & 8649 & 10509 \\
\hline
\end{tabular}




\begin{tabular}{|r|c|r|r|r|r|}
\hline 19 & 113 & 95 & 12769 & 9025 & 10735 \\
\hline 20 & 100 & 93 & 10000 & 8649 & 9300 \\
\hline 21 & 93 & 85 & 8649 & 7225 & 7905 \\
\hline 22 & 113 & 92 & 12769 & 8464 & 10396 \\
\hline 23 & 107 & 72 & 11449 & 5184 & 7704 \\
\hline 24 & 112 & 86 & 12544 & 7396 & 9632 \\
\hline 25 & 119 & 91 & 14161 & 8281 & 10829 \\
\hline 26 & 113 & 91 & 12769 & 8281 & 10283 \\
\hline 27 & 100 & 94 & 10000 & 8836 & 9400 \\
\hline 28 & 74 & 85 & 5476 & 7225 & 6290 \\
\hline 29 & 99 & 85 & 9801 & 7225 & 8415 \\
\hline 30 & 120 & 68 & 14400 & 4624 & 8160 \\
\hline 31 & 105 & 94 & 11025 & 8836 & 9870 \\
\hline 32 & 106 & 91 & 11236 & 8281 & 9646 \\
\hline 33 & 104 & 87 & 10816 & 7569 & 9048 \\
\hline 34 & 109 & 72 & 11881 & 5184 & 7848 \\
\hline 35 & 116 & 85 & 13456 & 7225 & 9860 \\
\hline 36 & 89 & 95 & 7921 & 9025 & 8455 \\
\hline 37 & 116 & 83 & 13456 & 6889 & 9628 \\
\hline 38 & 76 & 90 & 5776 & 8100 & 6840 \\
\hline 39 & 98 & 97 & 9604 & 9409 & 9506 \\
\hline 40 & 101 & 93 & 10201 & 8649 & 9393 \\
\hline jumlah & 3984 & 3452 & 404036 & 300070 & 343555 \\
\hline
\end{tabular}

Berdasarkan Tabel tersebut selanjutnya data tersebut diolah secara manual yakni menggunakan tabel anava sebagi berikut:

Tabel 2

Tabel Analisis Varians

\begin{tabular}{|c|c|c|c|c|c|}
\hline $\begin{array}{l}\text { Sumber } \\
\text { Varians }\end{array}$ & Db & JK & RJK & F Hitung & F Tabel \\
\hline A & 1 & 297907 & 297907 & \multirow{3}{*}{11,702} & \multirow{3}{*}{7,31} \\
\hline B & 1 & 5067 & 5067 & & \\
\hline Sisa & $\mathrm{N}-2$ & 2197,9 & 0,433 & & \\
\hline
\end{tabular}

Keterangan :

JK : Jumlah Kuadrat

RJK : Rata - rata jumlah kuadrat 
Berdasarkan tabel Anava di atas, hasil pengujian keberartian regresi diperoleh F hitung sebesar 11,702 lebih besar dari $\mathrm{F}$ tabel sebesar 7,31 pada dk pembilang $1 \mathrm{dan}$ dk penyebut 38 dan taraf nyata $\alpha=0,05$ sehingga dapat disimpulkan bahwa persamaan regresi $\hat{Y}=4,72+3,45$ $\mathrm{X}$. adalah signifikan (berarti). Sehingga dapat disimpulkan bahwa hubungan perhatian orang tua $(\mathrm{X})$ dengan hasil belajar (Y) adalah linear.

Kekuatan hubungan perhatian orang tua (X) terhadap hasil belajar PAI (Y) dapat ditunjukkan oleh koefisien jalur (p). untuk menghitung koefisien jalur atau koefisien pengaruh variabel X terhadap variabel Y (Pxy) digunakan rumus sebagai berikut :

$$
\begin{aligned}
& P_{x y}=r_{x y} \\
& r_{x y}=\text { koefisien korelasi ditentukan dengan rumus product mo ment } \\
& r_{x y}=\frac{N(\Sigma X Y)-(\Sigma X)(\Sigma Y)}{\sqrt{\left(N\left(\sum X^{2}\right)-\left(\sum X\right) M\left(\sum Y^{2}\right)-\left(\sum Y\right) I^{4}\right.}} \\
& r_{x y}=\frac{(40)(343555)-(3984)(3452)}{\sqrt{\left\{(40)(404036)-3984^{2}\right\}\left\{(40)(300070)-3452^{2}\right\}}} \\
& r_{x y}=\frac{10568}{158155}=0,066 \\
& \text { Dengan demikian } P_{x y}=r_{x y}=0,066
\end{aligned}
$$

Selanjutnya dilakukan uji t untuk mengetahui signifikan pengaruh X terhadap Y. Untuk mengetahui t hitung digunakan rumus sebagai berikut;

$$
\begin{aligned}
& \mathrm{t}_{\text {hitung }}=\frac{\mathrm{r} \sqrt{\mathrm{n}-2}}{\sqrt{1-\mathrm{r}^{2}}}=\frac{0,066 \sqrt{40-2}}{\sqrt{1-0,066^{2}}}=\frac{0,406}{0,966}=0,420 \\
& \text { Dan } \mathrm{t}_{\text {tabel }}=7,31 \text { dengan } \mathrm{dk}=38 \text { dan taraf nyata } \alpha=0,05
\end{aligned}
$$

Karena thitung lebih besar dari t tabel maka koefisien hubungan $(\mathrm{P}=0,420)$ signifikan. Artinya hipotesis yang menyatakan bahwa terdapat hubungan yang signifikan antara perhatian orang tua dengan hasil belajar, diterima.

Koefisien determinasi $\mathrm{X}$ terhadap $\mathrm{Y}$ adalah sebesar $(0,420) 2=0,1764$ sehingga $\mathrm{X}$ memberikan sumbangan (kontribusi) sebesar 17,64\%. Artinya $17 \%$ variansi hasil belajar (Y) dapat dijelaskan oleh variabel perhatian orang tua $(\mathrm{X})$ melalui regresi $\hat{Y}=4,72+3,45 \mathrm{X}$.

Berdasarkan analisis diatas menunjukkan bahwasannya pengaruh perhatian orang tua sangat signifikan terhadap hasil belajar siswa. Hal ini dikuatkan hasil wawancara dengan kepala 
sekolah dan salah seorang guru Sebagaimana diungkapkan oleh Tohari seorang kepala sekolah di sekitar perumahan Peran orang Tua terutama dari segi perhatian harus tetap ditingkatkan sehingga memotivasi belajar siswa dan prestasi siswa melonjak tajam yaitu dengan mengkolaborasikan serta sinergitas antara pihak sekolah dengan orang tua sehingga hasil belajr siswa maksimal meski terkendala tanpa adanya tatap muka di sekolah.

\section{KESIMPULAN}

Penelitian ini terdapat pengaruh positif dan signifikan Perhatian Orang Tua terhadap Hasil Belajar di Perumahan Graha Mas Serpong Utara. Hal ini menunjukkan bahwa semakin baik Perhatian Orang Tua terhadap anaknya maka Hasil Belajar akan semakin baik pula. Perlu upaya untuk meningkatkan kesadaran akan pentingnya Perhatian Orang Tua pada anak untuk dapat lebih memberikan perhatian yang sesuai dengan kebutuhannya, sehingga diharapkan hasil belajarnya juga meningkat. Misalnya dengan pemberian fasilitas yang menunjang kegiatan belajarnya, pemberian hadiah jika anak berprestasi.

\section{DAFTAR PUSTAKA}

Akbar, R., \& Hawadi. 2004. Akselerasi: A-Z Program Percepatan Belajar dan Anak Berbakat Intelektual.Jakarta: Grasindo.

Dimyati. 2006. Belajar dan Pembeljaran. Jakrta: Rineka Cipta

Djiwandono, S. E. 2002. Psikologi Pendidikan.Jakarta: Grasindo. h.7

Majid, A. (2008). Perencanaan Pembelajaran.Bandung: Remaja Rosdakarya.

Mohamad, N., Dahari, D., \& Utama, M. M. A. (2021). Konsep Dan Strategi Menciptakan Pendidikan Karakter Di Madrasah. Jurnal Asy-Syukriyyah, 22(1): 60.

Nemeth, J., \& Long, J. G. (2012). Assessing Learning Outcomes in U.S. Planning Studio Courses. Journal of Planning Education and Research, 32(4), 476-490.

Rita Ningsih. (2016). Pengaruh kemandirian Belajar,dan Perhatian Orang Tua Terhadap Prestasi Belajar Matematika. Jurnal Formatif, 6(1): 76.

Rofiqul A'la dan Muhamad Rifa'i Subhi, (2016) “Perhatian Orang Tua dan Motivasi Belajar Siswa," Jurnal Madaniyah 6(2).: 249

Walgito, Bimo. 2002. Pengantar Psikologi Umum. Yogyakarta: Andi Offset.

Wiyono, M. 2009. Profesionalisme Dosen dalam Program Penjaminan Mutu. Jurnal Ilmu Pendidikan, 16 (1): 51-58. 
Yamin, H.M. 2007. Profesionalisasi Guru \& Implementasi KTSP. Jakarta: GaungPersada Press.

Young, M. E., Klemz, B. R., \& Murphy, J. W. (2003). Enhancing Learning Outcomes: The Effects of Instructional Technology, Learning Style, Instructional Methods and Student Behavior. Journal of Marketing Education, 25, 13 